Fakultas Hukum Universitas Lancang Kuning, Jalan Yos Sudarso KM 8 Rumbai Pekanbaru, Riau, Kode Pos 28266. Telp: (+62761)-51877

E-mail: jurnal.respublica@ac.id

Website: https://journal.unilak.ac.id/index.php/Respublica

\title{
Analisis Yuridis Pembubaran Perseroan Terbatas (PT) Yang Tidak Beroperasi (Studi \\ Putusan Mahkamah Agung Nomor 1618 K/Pdt/2016 dan Putusan Mahkamah \\ Konstitusi Nomor 63/PUU-XVI/2018)
}

\author{
Priscila Patricia Yosephin \\ Magister Kenotariatan Fakultas Hukum, Universitas Sumatera Utara Indonesia, Email: \\ priscilayosephin@gmail.com
}

\begin{tabular}{l} 
Article Info \\
\hline Article History: \\
Received : $30-09-2021$ \\
Revised $\quad: 01-10-2021$ \\
Accepted : $05-10-2021$ \\
Published $\quad: 01-11-2021$ \\
\hline
\end{tabular}

\section{Keywords:}

Dissolution

Limited Liability Company

Directors

Not Operating

\section{Informasi Artikel}

\begin{tabular}{ll}
\hline \multicolumn{2}{l}{ Histori Artikel: } \\
Diterima $\quad: 30-09-2021$ \\
Direvisi $\quad: 01-10-2021$ \\
Disetujui $\quad: 05-10-2021$ \\
Diterbitkan & $: 01-11-2021$
\end{tabular}

\section{Kata Kunci:}

Pembubaran

Perseroan Terbatas

Direksi

Tidak Beroperasi

\begin{abstract}
Juridical Analysis of the Dissolution of Limited Liability Companies (PT) That Are No Longer Operating (Study of Supreme Court Decision No.1618 K/Pdt/2016 and Constitutional Court Decision No.63/PUU$\mathrm{XVI} / 2018$ ). This research method is normative juridical research, research this is juridical analytical. Based on the juridical analysis of the dissolution of a non-operating PT in the decision Number 1618 $\mathrm{K} / \mathrm{PDT} / 2016$, the Panel of Judges is of the opinion that it is the board of directors who has the right to submit a letter to the tax agency regarding the inactivity of a PT. Similarly, regarding the review of the material for the explanation of article 146 paragraph 1 letter C of the Company Law in the Constitutional Court Decision No. 63/PUU-XVI/2018, the Panel of Judges is of the opinion that the explanation of the article is unconstitutional and has provided a sufficient explanation that although it is not stated that the board of directors is an organ The PT that submits a letter to the tax agency regarding the inactivity of the PT, it must be clearly understood that the PT Law provides that management responsibility is only carried out by the board of directors. With this analysis, as a suggestion, it is hoped that in the future a more firm and clear legal rule will be made so that there are no differences in interpretation, especially in understanding the explanation of Law Number 40 of 2007 concerning Limited Liability Company

Abstrak
\end{abstract}

Analisis Yuridis Atas Pembubaran Perseroan Terbatas (PT) Yang Tidak Lagi Beroperasi (Studi Putusan Mahkamah Agung No.1618 K/Pdt/2016 dan Putusan Mahkamah Konstitusi No.63/PUU-XVI/2018).Metode penelitian ini adalah penelitian yuridis normatif, penelitian ini bersifat yuridis analitis. Pembubaran PT yang tidak beroperasi dalam putusan Nomor 1618 K/PDT/2016, maka Majelis Hakim berpendapat bahwa direksilah yang berhak untuk menyampaikan surat kepada instansi pajak terkait ketidakaktifan suatu PT. Demikian pula terkait uji materi penjelasan pasal 146 ayat 1 huruf C UU PT dalam Putusan Mahkamah Konstitusi No 63/PUU-XVI/2018, Majelis Hakim berpendapat bahwa penjelasan tentang pasal tersebut tidak inkonstutisional dan telah memberikan penjelasan yang cukup bahwa meskipun tidak disebutkan direksi sebagai organ PT yang menyampaikan surat kepada instansi pajak terkait ketidakaktifan PT, harus secara jelas dipahami UU PT memberikan tanggung jawab kepengurusan hanya dilakukan oleh direksi. 


\section{PENDAHULUAN}

Semenjak tahun 1967, ketika pemerintah mulai memacu pertumbuhan perekonomian nasional dengan mengeluarkan kebijakan penanaman modal asing, banyak orang berlombalomba dalam mendirikan perusahaan perseroan terbatas (PT). Pemilihan PT sebagai badan usaha yang banyak dipilih tentunya beralasan karena PT sebagai bentuk badan usaha dirasa mempunyai kelebihan dibanding badan usaha lainnya. ${ }^{1}$

Suatu perseroan terbatas sebagai badan hukum mempunyai ciri-ciri sebagai berikut yakni :2

a. Adanya harta kekayaan yang terpisah

b. Mempunyai tujuan tertentu.

c. Mempunyai kepentingan sendiri.

d. Ada organisasi yang teratur.

Perseroan terbatas sebagai badan hukum, lahir dan diciptakan berdasarkan proses hukum. Sebagai syarat sahnya pendirian perseroan maka syarat yang harus dipenuhi adalah perseroan harus didirikan oleh 2 (dua) orang atau lebih, pendirian dalam bentuk akta notaris, dibuat dalam Bahasa Indonesia, setiap pendiri wajib mengambil saham, serta telah mendapat pengesahan dari Menteri Hukum dan Hak Asasi Manusia karena didirikan dengan proses hukum maka proses penghentian perseroan juga harus melalui proses hukum. Pada Perseroan Terbatas telah mengatur pembubaran perseroan terjadi karena: ${ }^{3}$

1. Berdasarkan keputusan RUPS.

2. Karena jangka waktu berdirinya yang ditetapkan dalam Anggaran Dasar telah berakhir.

3. Berdasarkan penetapan pengadilan.

4. Dengan dicabutnya kepailitan berdasarkan putusan pengadilan niaga yang telah mempunyai kekuatan hukum tetap, harta pailit Perseroan tidak cukup untuk membayar biaya kepailitan

\footnotetext{
${ }^{1}$ (Agus Budiarto, Marger Bank, Ghalia Indonesia, Jakarta, 2009 hal 1)

2 (Riduan Syahrani, seluk Beluk Asas Hukum Perdata, Citra Aditya Bakti, Bandung, 2000 hal 61)

${ }^{3}$ pasal 142 ayat 1 Undang-Undang Nomor 40 Tahun 2007 tentang Perseroan Terbatas
} 
5. Karena harta pailit perseroan yang telah dinyatakan pailit berada dalam keadaan insolvensi sebagaimana diatur dalam Undang-undang tentang kepailitan dan Penundaan Kewajiban Pembayaran Utang;atau

6. Karena dicabutnya izin usaha Perseroan sehingga mewajibkan Perseroan melakukan likuidasi sesuai dengan ketentuan peraturan perundang-undangan.

Dalam proses pembubaran perseroan dalam praktiknya banyak mengalami kendala terkhususnya berbagai permasalahan di antara organ di dalam perseroan, sehingga dimungkinkan memilih penetapan pengadilan sebagai salah satu cara untuk melakukan pembubaran perseroan. Konflik-konflik kepentingan yang sering terjadi yakni karena kepemilikan saham yang berimbang di dalam perseroan terbatas tersebut.

Kepemilikan berimbang terjadi tidak menentukan secara khusus besarnya saham yang dapat dimiliki oleh pemegang saham namun hanya mengatur syarat bahwa pendiri perseroan harus berjumlah 2 (dua) orang atau lebih ${ }^{4} \mathrm{PT}$ yang dimiliki oleh 2 (dua) orang pemegang saham dengan kepemilikan saham berimbang tersebut tentunya akan sulit untuk mencapai kuorum dalam hal terdapat salah satu pemegang saham yang tidak menyetujui usulan RUPS dan keputusan sirkuler manakala terjadi ketidakharmonisan antar 2 (dua) pemegang saham tersebut.

Dalam hal tidak tercapai pembubaran perseroan terbatas melalui RUPS karena hal demikian maka upaya yang dapat dilakukan terhadap pembubaran perseroan adalah pembubaran perseroan melalui penetapan pengadilan negeri. Secara jelas dalam Pasal 146 ayat 1 Undang-Undang PT diatur bahwa pengadilan negeri dapat membubarkan Perseroan atas:

a. Permohonan kejaksaan

b. Permohonan pihak yang berkepentingan

c. Permohonan pemegang saham, direksi atau dewan komisaris

Berdasarkan beberapa poin yg dikemukakan di dalam pasal 146 ayat 1 UndangUndang PT tersebut, maka apabila salah satu syarat terpenuhi maka suatu PT dapat dibubarkan melalui Penetapan Pengadilan Negeri. Hal yang menarik untuk dibahas mengenai pembubaran perseroan terbatas ini adalah pembubaran perseroan terbatas melalui pengadilan. Salah satu syarat pembubaran suatu perseroan terbatas yang tertuang dalam penjelasan pasal

\footnotetext{
4 (M.Yahya Harahap, Hukum Acara Perdata, Sinargrafika, Jakarya, 2015 hal 161)
} 
146 UUPT adalah perseroan tersebut tidak lagi beroperasi yang dibuktikan dengan memberitahukan surat kepada instansi pajak.

Menarik untuk membahas suatu permohonan pembubaran PT yang dimohonkan kepada Pengadilan Negeri Jakarta Pusat, akan tetapi permohonan tersebut ditolak karena legal standing yang memberitahukan surat kepada instansi pajak tidak sesuai. Kasus tersebut berupa permohonan Penetapan Pengadilan Negeri Jakarta Pusat Nomor 176/k/pdt.p/2015 yang berlanjut melalui upaya hukum kasasi dengan Putusan Nomor 1618/k/pdt/2016.

Secara runut duduk perkara daripada permohonan tersebut ialah antara PT Artha Komodititi \& Energi Services (PT AKES), yakni merupakan sebuah PT yang didirikan berdasarkan persekutuan modal oleh para pemilik modal antara PT Republik Energi Metal dan PT Baraventura Pratama (PT BVP) sebagai pemilik modal tersebut. Berdasarkan keterrangan PT AKES tidak lagi beroperasi dan salah satu pemegang saham PT AKES ingin melakukanpembubaran, Karena tidak tercapai pembubaran perseroan terbatas melalui mekanisme RUPS maka salah satu pemegang saham yakni PT Baraventura Pratama (PT BVP) melayangkan permohonan pembubaran terhadap PT AKES karena berdasar pada Pasal 142 ayat 1 huruf c Undang-Undang PT, bahwa pembubaran perseroan dapat terjadi berdasarkan penetapan pengadilan. Dimana persyaratan pembubaran PT melalui penetapan pengadilan adalah berdasar pada pasal 146 UU PT yang menyatakan PT tidak lagi aktif selama kurang lebih tiga tahun dan dalam penjelasan pasal 146 UU PT tersebut dapat dibuktikan dengan penyampaian surat kepada instansi pajak. Dalam kasus ini yang menyampaikan surat kepada instansi pajak bahwa PT tidak lagi beroperasi selama 3 tahun atau lebih adalah PT Braventura Pratama sebagai salah satu pemegang saham.

Namun, dalam kenyataannya pengadilan negeri menolak permohonan PT BVP untuk membubarkan PT.AKES melalui penetapan pengadilan, karena menurut pengadilan gugatan yang dilayangkan adalah kabur. Dalam kasus ini yang menyampaikan surat pemberitahuan kepada instansi pajak adalah salah satu pemegang saham sendiri yaitu PT BVP, maka permohonan pembubaran perseroan terbatas tersebut masih prematur ${ }^{5}$

Bertalian dengan kasus sebelumnya, salah satu pihak dalam putusan Mahkamah Agung Nomor 1618 k/Pdt/2016 bersama-sama dengan pemohon lainnya melayangkan gugatan kepada Mahkamah Konstitusi. Dalam Putusan Mahkamah Konstitusi Nomor

\section{${ }^{5}$ ibid}


63/PUU-XVI/2018, para pemohon melayangkan permohonan kepada Mahkamah Konstitusi untuk melakukan pengujian materi terhadap pasal 146 ayat 1 huruf c Undang-Undang Nomor 40 Tahun 2007 tentang Perseroan Terbatas terkait pada penjelasan pasal 146 ayat 1 huruf c tentang kewenangan organ PT yang berhak untuk menyampaikan surat pemberitahuan kepada instansi pajak.

Dalam putusan Mahkamah Konstitusi ini adalah dalam Putusan Nomor 63/PUUXVI/2018 yang mengajukan uji materi kepada Mahkamah Konstitusi adalah PT BVP yang diwakili oleh Erwin Sutanto selaku direktur (kualifikasi pemohon dalam hal ini sebagai badan hukum privat), Zainal Abidinsyah Siregar selaku pemegang saham PT ARTHA NUSA SEMBADA (kualifikasi pemohon dalam hal ini sebagai perorangan warga negara Indonesia), dan Erwin Sutanto selaku pemegang saham PT ASSERA CAPITAL (kualifikasi pemohon dalam hal ini sebagai perorangan warga negara Indonesia).

Pemohon dalam hal ini menganggap hak dan/atau kewenangan konstitusionalnya dirugikan, dimana berdasar pada bunyi penjelasan Pasal 51 ayat (1) UU MK menyatakan yang dimaksud dengan hak konstitusional adalah hak-hak yang diatur dalam Undang-Undang Dasar Negara Republik Indonesia Tahun 1945.

Dalam hal ini pemohon I sebelumnya dalam perkara Pengadilan Negeri Jakarta Pusat memohonkan untuk melakukan pembubaran terhadap PT AKES, dimana pengadilan menyatakan bahwa permohonan tersebut premateur karena sebagaimana dinyatakan dalam Pasal 146 ayat (1) huruf C undang-undang PT menyatakan bahwa: permohonan pemegang saham, direksi atau dewan komisaris berdasarkan alasan Perseroan tidak mungkin dilanjutkan. Dasar permohonan pembubaran tersebut juga merujuk kepada Penjelasan Pasal 146 ayat (1) huruf c butir a yang menjelaskan bahwa yang dimaksud dengan alasan perseroan tidak mungkin dilanjutkan antara lain: a perseroan tidak melakukan kegiatan usaha (non-aktif) selama 3 (tiga) tahun atau lebih, yang dibuktikan dengan surat pemberitahuan yang disampaikan kepada instansi pajak.

Dalam permohonan di Pengadilan Negeri Jakarta Pusat, yang membuktikan perseroan tidak melakukan kegiatan usaha (non aktif) selama 3 tahun atau lebih melalui surat pemberitahuan yang disampaikan kepada instansi pajak, disampaikan oleh pemohon I yakni PT BVP selaku pemegang saham. Namun dalam pertimbangannya hakim pengadilan Jakarta Pusat berpendapat lain, dimana hanya direksi yang bisa menyampaikan surat pemberitahuan bahwa perseroan tidak lagi aktif, karena direksi adalah organ perseroan yang memiliki tugas 
untuk mengurus perseroan sesuai dengan maksud dan tujuan serta bertindak mewakili perseroan baik di dalam maupun di luar pengadilan. Karena dalam hal ini hakim berpendapat bahwa permohonan premateur maka pemohon I merasa norma yang terdapat dalam penjelasan Pasal 146 ayat (1) huruf C UUPT tersebut menimbulkan ketidakpastian hukum. Dalam hal ini pemegang saham merasa bahwa upaya yang dilakukan berupa pengajuan gugatan ke Mahkamah konstitusi adalah sebagai upaya untuk mendapat kepastian hukum dan perlindungan hukum terkhususnya bagi pemegang saham.

Namun, dalam kasus ini Majelis Hakim Mahkamah Konstitusi berpendapat lain, majelis hakim berpendapat bahwa penjelasan pasal 146 ayat 1 huruf $\mathrm{C}$ sudah sesuai dan menolak permohonan PT BVP karena tidak beralasan menurut hukum, sehingga dalam hal ini pemegang saham merasa tidak tercapai kepastian hukum dan perlindungan hukum. Pentingnya perlindungan hukum kepada pemegang saham apabila terdapat suatu konflik antar organ di dalam PT terkhususnya apabila direksi tidak melaksanakan tugasnya memberitahukan ketidakaktifan Perseroan terbatas kepada instansi terkait dalam proses pembubaran perseroan terbatas yang tidak beroperasi menjadi suatu masalah yang menarik untuk ditelaah, dengan demikian artikel ini membahas tentang "Analisis Yuridis Atas Pembubaran Perseroan Terbatas (PT) Yang Tidak Lagi Beroperasi (Studi Putusan Mahkamah Agung No.1618 K/Pdt/2016 dan Putusan Mahkamah Konstitusi No.63/PUU-XVI/2018).”

\section{ANALISIS DAN PEMBAHASAN}

\section{A. Kedudukan Direksi Dan Pemegang Saham Dalam Pembubaran Perseroan Terbatasa (PT) Yang Tidak Lagi Beroperasi}

Menurut penjelasan Pasal 146 huruf c Undang-Undang Nomor 40 Tahun 2007, untuk dapat dikatakan bahwa suatu perseroan tidak beroperasi adalah penjelasan pasal 146 huruf c point pertama yang mengatakan bahwa Perseroan yang tidak melakukan kegiatan usaha (nonaktif) selama 3 (tiga) tahun atau lebih, yang dibuktikan dengan surat pemberitahuan yang disampaikan kepada instansi pajak. Pasal 1 angka 5 jo Pasal 92 jo Pasal 98 UU PT No 40 Tahun 2007 menjelaskan bahwa direksi adalah organ perseroan yang berwenang dan bertanggung jawab penuh atas pengurusan perseroan, sesuai dengan maksud dan tujuan perseroan serta mewakili perseroan, baik di dalam maupun di luar pengadilan sesuai dengan ketentuan Anggaran Dasar. 
Dalam pasal 97 ayat (2) juga menjelaskan bahwa pengurusan yang dilakukan oleh direksi wajib dilaksanakan dengan iktikad baik dan penuh tanggung jawab. Maka jelas pula bahwa direksi memiliki kewenangan untuk menyampaikan surat kepada instansi pajak bahwa suatu PT sudah tidak beroperasi agar pengadilan dapat mengabulkan permohonan pembubaran PT melalui penetapan pengadilan tersebut.

Di dalam Pasal 146 ayat (1) huruf c memberikan kapasitas legal standing kepada pemegang saham, direksi ataupun dewan komisaris untuk mengajukan permohonan pembubaran perseroan kepada pengadilan negeri, penjelasan pasal 146 ayat (1) huruf c menjelaskan bahwa, pembubaran perseroan melalui penetapan pengadilan harus memenuhi syarat salah satu diantaranya yakni perseroan tidak melakukan kegiatan usaha (non-aktif) selama 3 (tiga) tahun atau lebih, yang dibuktikan dengan surat pemberitahuan yang disampaikan kepada instansi pajak.

Dalam melakukan pemberitahuan kepada instansi pajak, penjelasan pasal 146 ayat (1) huruf c butir a tidak menjelaskan secara tegas bahwa organ PT yang berhak untuk menyampaikan surat kepada instansi pajak hanyalah direksi. Maka dengan tidak adanya penegasan bahwa direksilah organ PT yang dapat menyampaikan surat kepada instansi pajak terkait ketidakaktifan PT, akan membuka kemungkinan bagi organ lainnya untuk melakukan penyampaian tersebut.

\section{B. Kepastian Hukum Terhadap Kedudukan Direksi dan Pemegang Saham Terkait Proses Pembubaran Perseroan Terbatas (PT) Yang Tidak Beoperasi Dalam Putusan Mahkamah Agung Nomor 1616 K/Pdt/2016 dan Putusan Mahkamah Konstitusi Nomor 63/Puu-XVI/2018}

Isu hukum yang termuat dalam penetapan oleh pengadilan negeri Jakarta Pusat Nomor 176/PDT.P/2015/PN.JKT.PST adalah mengenai permohonan salah satu pemegang saham perseroan terbatas, yang menginginkan pembubaran perseroan melalui penetapan pengadilan dimana hal ini didasarkan pada Pasal 146 ayat (1) huruf c UU NO 40 Tahun 2007 tentang perseroan terbatas dimana salah satu syarat untuk membubarkan perseroan dapat dilakukan melalui penetapan pengadilan, dengan merujuk kepada Penjelasan pasal 146 ayat (1) huruf c UU NO 40 Tahun 2007 butir a yang menyatakan bahwa syarat perseroan dapat dibubarkan oleh pengadilan yakni dengan syarat bahwa perseroan sudah tidak aktif (non aktif) selama kurang lebih 3 tahun dengan dibuktikan surat kepada instansi pajak. 
Dalam perkara ini yang menjadi isu adalah pengadilan mengganggap bahwa permohonan pemohon premateur karena yang menyampaikan surat kepada instansi pajak adalah pemegang saham, sebagaimana undang-undang PT mensyaratkan bahwa yang melakukan kegiatan untuk dan atas nama PT, serta untuk bertindak didalam dan diluar pengadilan seharusnya adalah direksi sebagai organ PT yang memiliki tanggung jawab dan wewenang atas hal tersebut, sehingga menganggap permohonan pemohon adalah premateur.

Karena merasa tidak tercapai kepastian hukum maka para pemohon dalam putusan mahkamah agung sebelumnya melayangkan permohonan uji materi kepada Mahkamah Konstitusi terkait penjelasan pasal 146 UU PT, isu hukum dalam perkara Nomor 63/PUU$\mathrm{XVI} / 2018$ adalah terkait pengujian undang-undang, dalam hal ini yang menjadi permasalahan adalah siapa yang memiliki wewenang dalam menyampaikan surat pemberitahuan yang disampaikan kepada instansi pajak. Pemohon dalam hal ini merasa bahwa dengan keberadaan norma yang dimuat dalam penjelasan Pasal 146 ayat (1) huruf c butir a UUPT telah menimbulkan ketidakpastian hukum terhadap norma yang sudah bersifat pasti dalam pasal 146 ayat (1) huruf c UU PT No 40 Tahun 2007. Dimana menurut pemohon, keputusan memaknai penjelasan Pasal 146 ayat (1) huruf c butir a UUPT sebagai Tindakan kepengurusan direksi sebagaimana yang telah dilakukan oleh pengadilan negeri Jakarta Pusat dan Mahkamah Agung dalam dua putusan yang disebut diatas adalah bertentangan dengan Pasal 146 ayat (1) huruf C UU PT No 40 Tahun 2007.

Dalam Putusannya, pemohon mengajukan pertanyaan mengenai pasal 146 normanya membuka ruang kepada tiga komponen, direksi, dewan komisaris atau pemegang saham tetapi menurut pemohon penjelasan pasalnya mengerucut hanya kepada direksi, kemudian dalam penjelasan normanya justru menambah syarat baru yakni adanya syarat pemberitahuan ke instansi pajak. Dimana pemohon juga menjelaskan bahwa dalam penjelasan tersebut tidak disebutkan secara langsung siapa yang berwenang mengajukan kepada instansi pajak.

Dalam permohonan, pemohon mempertanyakan darimana pemerintah menyimpulkan bahwa dalam penjelasan Pasal 146 ayat (1) huruf c butir a , yang berhak mengajukan surat adalah direksi. Sebagai akibat dari ketidakpastian hukum pada norma yang dimiat dalam penjelasan pasal 146 ayat (1) huruf c butir a UU PT No 40 Tahun 2007 tersebut, norma dalam pasal tersebut dimohonkan pengujian materinya kepada Mahkamah Konsititusi.

Dengan berbagai pertimbangan hukum, Mahkamah konstitusi berpendapat permohonan para pemohon berkenaan dengan inkonstitusionalitas penjelasan pasal 146 ayat 
(1) huruf c butir a UU PT No 40 Tahun 2007 tidak beralasan menurut hukum dan dalam amarnya menolak permohonan pemohon untuk seluruhnya.

Dalam kasus Penetapan Nomor 176/PDT.P/2015/PN JKT.PST dan Putusan MA Nomor 1618 K/PDT/2016 memberikan pertimbangan hukum yang sama yakni berdasar pada tanggung jawab serta kewajiban direksi seperti yang disyaratkan oleh hukum dan atau undang-undang sehingga memberikan kepastian hukum kepada direksi sebagai organ perseroan terbatas yang menjalankan dan mewakili perseroan dan telah memberikan kepastian hukum pula kepada pemegang saham terkait proses pembubaran perseroan terbatas yang dalam pertimbangan hukum hakim telah berdasar pada norma-norma hukum terkait namun dalam sisi lain menurut penulis akan memberikan ketidakadilan bagi pemegang saham. Hal ini dikarenakan pada PT in casu. Syarat pembubaran perseroan terbatas tidak dapat dibebankan kepada pemegang saham dan berpotensi dapat merugikan pemegang saham apabila PT tersebut tidak dibubarkan.

Hakim dalam amar putusan menyatakan bahwa PT AKES tidak mungkin dibubarkan berdasar pada alasan-alasan yang telah dikaji melalui undang-undang PT yang berlaku saat ini berdasar pada bahwa yang berhak mewakili PT dan menjalankan pengurusan terhadap perseroan adalah direksi saja. Dalam hal ini bukan legal standing pemegang saham dalam pengajuan permohonan yang menjadi permasalahan namun terhadap kepastian hukum direksi sebagai organ perseroan yang terbatas yang berhak untuk menyampaikan surat pemberitahuan kepada instansi pajak bahwa perseroan tidak lagi aktif selama 3 tahun atau lebih sehingga memungkinkan bahwa perseroan tersebut dibubarkan melalui penetapan pengadilan.

Dari amar putusan tersebut dapat disimpulkan bahwa pertimbangan hukum hakim terkait direksilah yang berhak untuk mengajukan surat pemberitahuan kepada instansi pajak adalah berdasar pada pasal 1 angka 5 jo pasal 97 ayat (1) UU PT sudah memberi kepastian hukum kepada direksi karena telah dijelaskan bahwa direksilah yang mewakili perseroan di dalam maupun di luar pengadilan serta melakukan pengurusan perseroan. Pertimbangan hukum hakim juga telah sesuai dengan norma-norma yang terdapat dalam UU PT No 40 Tahun 2007 serta telah memberi kepastian hukum kepada pemegang saham maupun direksi terkait proses pembubaran perseroan terbatas.

Namun penolakan permohonan penetapan pengadilan negeri Jakarta Pusat Nomor: 176/PDT.P/2016/PN.JKT.PST dan Putusan Mahkamah Agung Nomor 1618 K/PDT.P/2018 oleh pemohon dianggap tidak memberi kepastian hukum kepada pemegang saham selaku 
pemohon dalam permohonan tersebut sehingga pemohon merasa hak-hak konstitusional telah dirugikan daripada penetapan pengadilan dan putusan mahkamah agung tersebut. Dalam hal ini pemohon mengajukan permohonan kepada Mahkamah Konstitusi terhadap penjelasan pasal 146 ayat 1 huruf c butir a UU PT No 40 Tahun 2007 karena merasa bahwa hak-hak konstitusionalnya telah dirugikan dengan adanya pemaknaan pasal oleh hakim yang mengakibatkan ditolaknya permohonan pemohon. Dalam memaknai permohonan pemohon kepada Mahkamah Konstitusi, Majelis Hakim Mahkamah Konstitusi berpendapat bahwa permohonan pemohon adalah inkonstitusional dan tidak ada ketentuan yang bertentangan dengan hukum sehingga permohonan pengujian materi penjelasan pasal 146 huruf c UU PT No 40 Tahun 2007 ditolak oleh Majelis Hakim.

Terkait analisa terhadap Putusan MK Nomor 63/PUU-XVI/2018, dalam amar putusannya pada Putusan Mahkamah Konstitusi Nomor 63/PUU-XVI/2018 maka Mahkamah Konstitusi dengan amar menolak permohonan pemohon untuk seluruhnya mengenai pengujian atas penjelasan Pasal 146 ayat (1) huruf c undang-undang karena dinilai tidak beralasan menurut hukum. Putusan hakim konstitusi menyatakan permohonan ditolak, apabila permohonannya tidak beralasan. Dalam hal ini undang-undang dimaksud tidak bertentangan dengan Undang-Undang Dasar Negara Republik Indonesia Tahun 1945, baik mengenai pembentukannya maupun materinya sebahagian atau keseluruhan, maka amar putusannya menyatakan permohonan ditolak ${ }^{6}$

Putusan Mahkamah Konstitusi yang menolak permohonan para pemohon memperkuat kedudukan direksi sebagai organ perseroan terbatas yang menjalankan perseroan terbatas dan mewakili perseroan terbatas di luar maupun di dalam pengadilan. Dalam hal ini putusan mahkamah konstitusi juga telah memberikan kepastian hukum kepada pemegang saham dan direksi terkait proses pembubaran perseroan terbatas yang tidak beroperasi. Namun meskipun telah memberikan kepastian hukum kepada pemegang saham, Putusan Mahkamah Konstitusi ini belum memberikan keadilan terhadap posisi pemegang saham dalam hal pemegang saham ingin membubarkan perseroan terbatas. Putusan Mahkamah Konstitusi Nomor 63/PUUXVI/2018 menurut pemohon adalah inkonstitusional.

Dengan ditolaknya permohonan pemohon oleh majelis hakim Mahkamah Konstitusi dalam permohonan Nomor 63/PUU-XVI/2018 karena pemohon dianggap inkonstitusional,

\footnotetext{
${ }^{6}$ (Bambang SutiyosoPutusan Mahkamah Konstitusi dan Implikasinya Terhadap Pencari Keadilan”, Jurnal Hukum No 3 vol 15 Juli 2008)
} 
maka pada dasarnya telah memberi kepastian hukum kepada direksi maupun pemegang saham khususnya terkait syarat daripada permohonan pembubaran perseroan terbatas yang menurut majelis hakim, pemenuhan daripada syarat pemberitahuan ketidakaktifan perseroan kepada instansi pajak hanya dapat dilakukan oleh direksi selaku organ perseroan yang memiliki kewajiban melaksanakan pengurusan perseroan.

Apabila memaknai perseroan terbatas masih dalam keadaan belum defenitif bubar, baik direksi, komisaris dan RUPS masih dalam keadaan aktif. Dalam hal ini direksi masih dapat melakukan pengurusan perseroan apalagi dalam hal pengurusan itu bertalian dengan proses pembubaran perseroan yakni proses penyampaian perseroan tidak lagi aktif selama kurang lebih 3 tahun yang dibuktikan dengan penyampaian surat kepada instansi pajak. Pemahaman secara sistematik ini tetap didasari pada pasal 1 angka 5 jo Pasal 98 UU PT No 40 Tahun 2007 yang menyatakan bahwa direksi adalah organ perseroan yang berwenang serta bertanggung jawab melakukan pengurusan terhadap perseroan serta mewakili perseroan di dalam maupun di luar pengadilan.

Dalam putusan Mahkamah Konsitusi Nomor 63/PUU-XVI/2018 menegaskan bahwa tidak terdapat kekaburan norma dalam penjelasan pasal 146 ayat 1 butir c UU PT No 40 Tahun 2007 hal ini juga didasarkan bahwa terhadap Putusan Mahkamah Konstitusi terdahulu telah menyatakan bawha penjelasan tidak mempunyai kekuatan mengikat sehingga dapat memperluas atau menambah norma yang terdapat dalam batang tubuhnya. Penjelasan dapat dimaknai secara luas, maka hakim dalam menerapkan hukum pada Penetapan Pengadilan Negeri Jakarta Pusat Nomor 176/PDT.P/2016/PN.JKT.PST dan Putusan Mahkamah Agung Nomor 1618K/PDT.P/2018 dapat menafsirkan lebih luas penjelasan pasal 146 ayat 1 huruf c butir a UU PT No 40 Tahun 2007 tersebut.

Dalam hal persyaratan pembubaran perseroan terbatas adalah syarat materil maka pada dasarnya pembuktian tersebut dapat dibuktikan bahwa perseroan terbatas tidak lagi aktif berdasarkan keterangan lembaga-lembaga diluar instansi pajak. Namun apabila persyaratan pembubaran perseroan terbatas adalah syarat formil maka seyogyanya menurut penjelasan undang-undang surat ketidaaktifan PT hanya dapat disampaikan kepada instansi pajak.

Oleh karena tidak adanya kaidah-kaidah hukum yang dilanggar dalam penerapan hukum maka terhadap Penetapan Pengadilan Negeri Jakarta Pusat Nomor 176/PDT.P/2016/PN.JKT.PST dan Putusan Mahkamah Agung Nomor 1618K/PDT.P/2018 serta Putusan Mahkamah Konstitusi Nomor 63/PUU-XVI/2018 telah memberikan kepastian 
hukum baik kepada direksi maupun terhadap pemegang saham dalam proses pembubaran perseroan terbatas yang tidak beroperasi.

\section{Perlindungan Hukum Terhadap Pemegang Saham Apabila Direksi Tidak Melaksanakan Tugasnya Memberitahukan Kepada Instansi Terkait Dalam Proses Pembubaran Perseroan Terbatas Yang Tidak Beroperasi}

Apabila kelalaian yang dilakukan oleh direksi atau anggota direksi mengakibatkan kerugian bagi pemegang saham, maka Rapat Umum Pemegang Saham merupakan organ yang memiliki wewenang yang tidak diberikan kepada direksi dan/atau dewan komisaris, dapat menjatuhkan sanksi kepada anggota direksi yang sudah terbukti melakukan kesalahan dan merugikan perseroan.

Namun membawa suatu permasalahan ke dalam pembahasan RUPS sangat tergantung pada inisiatif dan iktikad baik pemegang saham mayoritas. Setiap keputusan RUPS selalu diambil berdasarkan suara mayoritas dalam hal keputusan musyawarah tidak dapat tercapai ${ }^{7}$ Dalam hal situasi yang terjadi adalah demikian, maka hal yang dapat dilakukan adalah dengan pengajuan gugatan derivatif untuk memberikan perlindungan bagi pemegang saham.

Gugatan derivatif ini akan memberikan hak kepada pemegang saham minoritas untuk mengambil tindakan luar biasa melalui pengadilan, dengan tujuan agar hak-hak tidak dirugikan dan seluruh hasil dari gugatan tersebut (misalnya dalam bentuk ganti rugi dari direksi) akan menjadi milik perseroan, bukan milik pemegang saham penggugat ${ }^{8}$ Selain pengajuan gugatan derivatif sebagai bentuk perlindungan hukum terhadap pemegang saham, apabila direksi lalai dalam pelaksanaan tugas dalam hal ini menyampaikan surat ketidakaktifan PT kepada instansi terkait, maka pemegang saham juga dapat mengajukan gugatan personal, dimana dalam kontek pemegang saham dapat melakukan tindakan atas nama mereka sendiri ( perseroan sebagai subjek hukum mandiri yang terpisah dan berbeda dengan pemegang saham atau pendirinya), meskipun tindakan ini sifatnya terbatas. Para pemegang saham juga memiliki hak untuk mengajukan permohonan kepada pengadilan untuk

7 (Bambang Sutiyoso, Hukum Arbitrase dan Penyelesaian sengketa, Gama Media, Yogyakarta, 2008, hal 357-358)

${ }^{8}$ (Munir Fuady, Doktrin-Doktrin Dalam Corporate Law dan Eksistensinya Dalam Hukum Indonesia, Bandung: PT. Citra Aditya Bakti, 2002 hal 99) 
pembubaran perusahaan dalam keadaan tertentu. (Keterangan Dr. Siti Anisah, S.H.,M.Hum dalam persidangan di Mahkamah Konstitusi)

Gugatan personal umumnya terkait dengan hak hukum maupun hak kontraktual pemegang saham, terkait dengan saham itu sendiri, atau terkait dengan kepemilikan saham dan hal-hal lain yang terkait dengan kedudukan selaku pemegang saham. UU PT No 40 Tahun 2007 memberikan hak bagi setiap pemegang saham untuk mengajukan gugatan terhadap perseroan apabila dirugikan karena tindakan perseroan yang dianggap tidak adil dan tanpa alasan wajar sebagai akibat keputusan RUPS, direksi, dan/atau dewan komisaris 9

\section{KESIMPULAN}

Adapun kesimpulan dari penelitian ini adalah, Perseroan terbatas merupakan badan hukum yang dibentuk melalui hukum maka dapat pula dibubarkan sesuai dengan hukum. Dalam hal perseroan tidak lagi beroperasi selama kurang lebih 3 tahun, maka direksi ataupun pemegang saham dapat mengajukan pembubaran perseroan terbatas melalui permohonan penetapan pengadilan. Hal yang paling sering mengakibatkan upaya pembubaran perseroan terbatas melalui pengadilan negeri selain tidak beroperasi juga karena keberimbangan kepemilikan saham dalam perseroan terbatas. Pasal 146 ayat (1) UU PT No 40 Tahun 2007 telah memberikan legal standing kepada direksi maupun pemegang saham untuk mengajukan permohonan terhadap pembubaran perseroan terbatas. Namun terhadap pemenuhan persyaratan daripada pembubaran perseroan terbatas melalui pengadilan berupa surat kepada instansi pajak terkait PT tidak lagi aktif selama 3 tahun atau lebih, masih terdapat perbedaan penafsiran norma terkait legal standing organ yang dapat menyampaikan surat kepada instansi pajak tersebut.

Dengan adanya penetapan Pengadilan Negeri Jakarta Pusat Nomor 176 K/PDT.P/PN.JKT PST, Putusan Mahkamah Agung Nomor 1618 K/PDT.P/2016, dan Putusan Mahkamah Konstitusi Nomor 63/PUU-X VI/2018 telah memberikan kepastian hukum kepada direksi maupun pemegang saham dalam proses pembubaran perseroan terbatas yang tidak beroperasi melalui pengadilan negeri. Dalam Penetapan Nomor 176 K/PDT.P/PN.JKT PST yang kemudian berlanjut melalui upaya hukum kasasi dengan Putusan Nomor 1618 K/PDT.P/2016, Majelis Hakim menolak permohonan pemohon untuk membubarkan perseroan terbatas melalui penetapan pengadilan dikarenakan pertimbangan hukum hakim

\footnotetext{
${ }^{9}$ (Taqiyuddin Kadir, Gugatan Derivatif perlindungan Hukum, Bumi Aksara, Jakarta, 2017, hal 31)
} 
yang menyatakan bahwa permohonan para pemohon premateur. Majelis hakim berpendapat berdasar pada penjelasan pasal 146 ayat 1 huruf c hanya direksi, organ PT yang berhak untuk menyampaikan surat kepada instansi pajak bahwa PT tidak lagi aktif yang merupakan syarat yang harus dipenuhi dalam permohonan pembubaran PT melalui penetapan pengadilan. Pemohon dalam hal ini pemegang saham kemudian mengajukan uji materi terhadap penjelasan pasal 146 ayat 1 huruf c tersebut kepada Mahkamah Konstitusi dimana dalam putusannya, Mahkamah Konstitusi juga menolak gugatan dari pemohon karena gugatan para pemohon inkonstitusional. Dalam hal ini baik penetapan hakim di PN Jakarta Pusat, Putusan Mahkamah Agung dan Putusan Mahkamah Konstitusi baik dalam penetapan maupun putusannya telah didasarkan pada norma-norma hukum yang berlaku dalam UU PT No 40 Tahun 2007, namun dalam hal ini pemegang saham tidak memperoleh keadilan melalui putusan majelis hakim tersebut karena tidak tercapainya keinginan untuk melakukan pembubaran perseroan terbatas tersebut yang mungkin saja dapat merugikan pihak pemegang saham jika pembubaran tersebut tidak dilakukan.

Dalam pembubaran perseroan terbatas melalui penetapan pengadilan, terdapat syarat bahwa untuk membuktikan suatu perseroan tidak aktif maka hal yang harus dilakukan adalah dengan memberitahukan bahwa suatu perseroan terbatas tidak lagi aktif dengan membuktikan surat tidak aktif kepada instansi terkait dalam hal ini adalah instansi pajak. Dalam hal pengurusan terhadap perseroan, maka yang menjalankan kewajiban pengurusan adalah direksi sebagai organ perseroan, namun dalam hal terdapat konflik kepentingan yang membuat posisi pemegang saham menjadi dirugikan maka perlindungan terhadap pemegang saham yang diatur oleh UU PT No 40 Tahun 2007 dapat melalui gugatan personal gugatan derivatif atau pun perlindungan melalui RUPS. Dalam hal direksi lalai dalam menyampaikan surat kepada instansi terkait, pemegang saham dapat mengambil langkah perlindungan melalui gugatan personal maupun gugatan derivatif dengan membuktikan bahwa pemegang saham tersebut menderita kerugian akibat kelalaian direksi yang tidak menyampaikan surat kepada instansi pajak terkait ketidakaktifan PT selama 3 tahun atau lebih sebagai syarat pembubaran PT yang tidak beroperasi melalui penetapan pengadilan.

\section{DAFTAR PUSTAKA}

\section{Buku}

Budiarto, Agus. 2009. Kedudukan Hukum dan Tanggung Jawab Pendiri Perseroan 
Terbatas. Mataram : Ghalia Indonesia.

Fuady, Munir. 2002. Doktrin-Doktrin Dalam Corporate Law dan Eksistensinya Dalam Hukum Indonesia, Bandung: PT. Citra Aditya Bakti.

Harahap, M.Yahya. 2010. Hukum Acara Perdata. Jakarta: Sinar Grafika. 2015. Hukum Perseroan Terbatas. Jakarta: Sinar Grafika.

Kadir, Taqiyuddin. 2017. Gugatan Derivatif Perlindungan Hukum Pemegang Saham Minoritas. Jakarta: Sinar Grafika.

Syahrani, Riduan. 2000. Seluk Beluk dan Asas-Asas Hukum Perdata. Bandung: Alumni.

\section{Peraturan Perundang-undangan}

Kitab Undang-Undang Hukum Perdata

Kitab Undang-Undang Hukum Dagang

Undang-Undang Nomor 40 Tahun 2007 Tentang Perseroan Terbatas

Penetapan PN Jakarta Pusat Nomor 176/PDT.P/2015/PN.JKT./PST

Putusan Mahkamah Agung Nomor 1618 K/Pdt/2016

Putusan Mahkamah Konstitusi Nomor 63/PUU-XVI/2018

Jurnal

Sutiyoso, Bambang. "Putusan Mahkamah Konstitusi dan Implikasinya Terhadap Pencari Keadilan”, Jurnal Hukum No 3 vol 15 Juli 2008. 